\title{
Artigo
}

\section{On social capital, creative class, emancipative values, and the rising for-right populism}

\author{
Sobre capital social, classe criativa, valores emancipativos e 0 \\ crescente populismo de extrema-direita
}

João Victor Guedes-Neto ${ }^{1}$

DOI: $10.5752 /$ P.1809-6182.2017v15.nl.pl

\begin{abstract}
Putnam (1995), Florida (2002) and Welzel (2013) have at least one common argument: social capital, in the way we knew it, is dying. According to new theories, it is being replaced by a different mode of interaction, marked by weak-ties relationships and benign individualism. If that is true, why is far-right populism becoming so strong in Western democracies? This paper does not aim at creating a new theory or at presenting a final answer for this question but rather at pointing out at why Richard Florida's and Christian Welzel's theories did not anticipate the rise of a 21'st-century mode of populism. As a core concluding element, I highlight the unforeseen triggering role played by increasing emancipative values in the mobilization of the now far-right electorate.
\end{abstract}

Key-words: Far-Right, Creative Class, Emancipative Values, Social Capital, Populism

\section{Resumo}

Putnam (1995), Florida (2002) e Welzel (2013) têm pelo menos um argumento em comum: o capital social, na forma com que o conhecíamos, está morrendo. De acordo com novas teorias, ele está sendo substituido por formas diferentes de interação, marcadas por relaçóes fracas e um individualismo benigno. Se isto é verdade, porque o populismo de extrema direita está ficando tão forte nas democracias ocidentais? Este artigo não tenta criar uma nova teoria ou apresentar uma resposta final para esta questão, mas sim apontar porque as teorias de Richard Florida e Christian Welzel não anteciparam a ascensão deste modelo de populismo do século XXI. Como um elemento de conclusão, destaco o inesperado papel desencadeador dos crescentes valores emancipativos na mobilizaçâo do agora eleitorado da extrema direita.

Palavras-chave: Extrema Direita, Classe Criativa, Valores Emancipativos, Capital Social, Populismo

1. Bacharel em Ciências Econômicas pela Universidade Federal de São João del-Rei. Mestre em Gestão Pública e Sociedade pela Universidade Federal de Alfenas. Mestre em Economia Pública, Direito e Sociedade na Leuphana Universität Lüneburg. Doutorando em Ciência Política na University of Pittsburgh. Orcid: 0000-0001-6881$\underline{1166}$ 


\section{Introduction}

Putnam (1995), Florida (2002), and Welzel (2013) have at least one argument in common: social capital, in the way we knew it, is dying. Still, both Richard Florida and Christian Welzel seem to be rather optimistic as they have also perceived the rise of benign forms of individualism, namely the creative class and emancipative values. They mean more innovative, diverse, and socially liberal individuals. If that is true, one should be puzzled by the concomitant rise of far-right parties. Why have Florida and Welzel failed to see this opposite trend?

Already two decades ago, Putnam (1995) based his assumption of the decline of social capital on, among other variables, the behavior of Americans when bowling. As he points out, "between 1980 and 1993 the total number of bowlers in America increased by 10 percent, while league bowling decreased by 40 percent" (PUTNAM, 1995, p.70). He also argued that different forms of civil engagement might have increased, for instance, participation at the Association of Retired Persons. Still, it took place in a different way, as "for the vast majority of their members, the only act of membership consists in writing a check for dues or perhaps occasionally reading a newsletter" (PUTNAM, 1995, p.71), instead of attending meetings and interacting with other members.

Seven years later, Florida (2002) argued that the old form of social capital, related to strong community bonds, was giving place to a new form of interaction: the creative capital. And it was rather positive once people, as he argued, "wanted community, but not to the extent that they were inhibited from living their own life and being themselves" (FLORIDA, 2002, p.269). In this sense, people were looking for "diversity, low entry barriers and the ability to be themselves" (FLORIDA, 2002, p.269). This desire gave birth to the creative capital and a creative class, characterized by weak ties that produced social interaction with a greater number of people without the bonds generated by Putnam's strong-tie relationships. According to Florida (2002, p.275), these characteristics would be found in the creative centers of large urban cities, which "have high levels of innovation and high-tech industry and very high levels of diversity, but lower than average levels of social capital and moderate levels of political involvement".

Whereas Welzel (2013) is also optimistic about this trend, he does not think that creating a new term is necessary. As he argues,

when pro-civic individualism dominates, the nature of social capital transforms. Indeed, I argue that pro-civic individualism brings a sea change from a dominance of imposed affiliations that chain us to prefixed groups toward chosen affiliations in which we are free to connect and disconnect as we like. Hence, individualization does not erode social capital; it transforms the nature of social capital, changing it from a captivating into a liberating property (WELZEL, 2013, p.192).

His data is solid in showing that regions and people with strong emancipative values, the basis for pro-civic individualism, are marked by an unselfish, trustful and humanistic behavior. Therefore, lone-bowlers, instead of being unsocial people, are more prone to create an equal and tolerant society.

One might be optimistic or pessimistic about it, but it is difficult to deny the trend presented by these three authors where the old form of social capital seems to be dying and being replaced by a different mode of interaction, marked by weak-tie relationships and benign individualism. On the other hand, some questions arise from this trend, for instance on the policy implications of this change and, as I will focus in the following sections, on how sustainable this trend is.

In light of the recent electoral forecasts and results in Western societies, if people are becoming 
positively individualistic and tolerant to diversity, why far-right populist political forces such as Freiheitliche Partie Österreichs (Austria), Front National (France), Perussuomalaiset (Finland), Alternative für Deutschland (Germany) and Partij voor de Vrijheid (the Netherlands) are becoming so strong?

My objective in this essay is not to create a new theory or to present an answer for that question, but rather to point out at some gaps and omissions in the assumptions and methods of Florida (2002) and Welzel (2013) that might have inhibited them to foresee the rise of a $21^{\text {st }}$-century mode of populism.

I divide my arguments into four sections, excluding this introduction and the conclusion. In the second section, I detail the core concepts discussed in this paper. Then, I present a brief review of the scientific and journalistic literature to clarify what I mean by $21^{\text {st }}$-century mode of populism. In the fourth, I expose how emancipative values and creative capital contrapose cultural protectionism a core element of the far-right populism. Thereafter, I discuss some gaps that may explain why these authors were not capable of foreseeing the current scenario. Finally, I reflect on negative implications and suggest methods and approaches that could have predicted the rise of the far-right and might be helpful to understand these recent events.

\section{Clarifying concepts}

Before moving ahead in the proposed discussion, I must explain the selected concepts and the context they are inserted in. I do so by presenting the post-materialist argument, in a certain way derived from the modernization theory, and the subsequent concepts of social capital, creative capital (and class), and emancipative values. Finally, as to prepare the basis for the following chapter, I discuss alternative meanings of populism.

\section{Modernization theory and post-materialism}

Corroborating to the central claim of modernization theory, Inglehart (1997, p.5) "argues that economic development, cultural change, and political change go together in coherent and even, to some extent, predictable patterns". He exemplifies it by citing the "diminishing differences in gender roles" after industrialization processes (INGLEHART, 1997). Post-materialism is a deriving phenomenon. In Inglehart's (1997, p.35) words, 'the term 'post-materialist' denotes a set of goals that are emphasized after people have attained material security, and because they have attained material security". The material versus post-material divide advances modernization theory, or, in other words, updates it to a more recent reality, by arguing that "postmaterialists do not place a negative value on economic and physical security - they value it positively, like everyone else; but unlike materialists, they give even higher priority to self-expression and the quality of life" (INGLEHART, 1997, p.35).

\section{Social capital}

The idea of social capital derives from modernization theory, as Putnam (1994) merges socioeconomic modernity and "patterns of civic involvement and social solidarity" to explain the higher levels of development in Northern Italy when compared to southern region of the same country (PUTNAM, 1994, p.83). In other words, there is a causal link between modernization and civic-ness, namely social capital, also explained as the "features of social organization, such as trust, norms, and networks, that can improve the efficiency of society by facilitating coordinated actions" (PUTNAM, 1994, p.167). In this sense, social capital becomes a triggering factor of development while, as a moral resource, being triggered by development. 


\section{Creative capital}

Creative capital refers to a specific type of human capital. It is an alternative to social capital, focused specifically on creative people as "scientists and engineers, university professors, poets and novelists, artists, entertainers, actors, designers, and architects, as well as the 'thought leadership' of modern society: nonfiction writers, editors, cultural figures, think-tank researchers, analysts, and other opinion-makers" (FLORIDA, 2003, p.7). Together, they compose Florida's (2003, p.10) " $3 T$ of economic development: technology, talent, and tolerance." As earlier said, creative and social capital are distinct as creative people tend to look for communities that do not tend to inhibit their own personal lifestyles, as Florida believed was the case of collectivist localities with a high level of social capital.

\section{Emancipative values}

Inglehart and Welzel (2005, p.248) affirm that "not all communal values and forms of social capital are equally important to democracy, but above all those that are motivated by people's aspiration for human freedom and choice". Categorically rejecting the evolution of Putnam's social capital as a synonymous to modernization, liberalization, and democratization, they argue that

emancipative values give priority to individual liberty over collective discipline, human diversity over group conformity, and civic autonomy over state authority. (...) They diminish people's dependence on inward-looking groups while integrating them into webs of looser but more diverse human interactions (WELZEL, 2005, p.248).

This idea is closer to Florida's concept of creative capital, as it focuses on weak-tie relationships and a liberalizing spirit. Still, it is operationalized in a different fashion. Instead of recurring to bohemian and gender aspects, Welzel (2013) uses a set of values extracted from the World Values Survey, namely toleration of abortion, divorce, and homosexuality; preference for women's equality in the job market, politics, and education; desirability of freedom of speech in both the national and local levels; independence and imagination as desired qualities; and obedience as a non-desired quality.

\section{Populism}

There are several ways of conceptualizing populism. Coniff (1999) posited attention to the charismatic relationship between leaders and masses, granting the label of populist to what could be seen as a renewed version of the Weberian charismatic domination. On the other hand, Kaufman and Stallings (1991) understood populism essentially through an economic point of view, crediting the label to politicians who managed to mobilize the support of the working class and domestic businesses by alienating rural oligarchies and implementing developmentalist reforms. Whereas both definitions were mostly related to the Latin American reality, Mudde and Kaltwasser's (2012) approach intended to create a general concept that could fit the realities of both Latin America and Europe. For that reason, his conceptual framework is more relevant to this work. In their words,

populism is defined here as a thin-centered ideology that considers society to be ultimately separated into two homogeneous and antagonistic groups, 'the pure people' and 'the corrupt elite,' and which argues that politics should be an expression of the volonté générale (general will) of the people (MUDDE; KALTWASSER, 2012, p.8).

The selected definition encompasses Coniffs (1999) populist-mass linkages while expanding Kaufman and Stallings's (1991) urban-rural dichotomy into a broader understanding of social dispute: the people versus the elite. As I shall further develop in the following chapters, as creative capital and emancipative values become mainstream, 
traditional peoples feel left behind and adhere to populist leaders who represent their protection against the newly raised liberal elite.

\section{$21^{\text {st }}$-century populism}

Vossen (2011) approaches the topic of populism by describing the ideological development of the Dutch politician Geert Wilders, leader of the Partij voor de Vrijheid. During his young-hood, Geert worked as a speechwriter at a mainstream right-wing liberal party, becoming a member of the parliament in 1998 as a pupil of the socially conservative Frits Bolkestein. Both were known for speaking against multiculturalism and being "willing to face facts that among the population were already well known" (VOSSEN, 2011, p.181). In the early 2000s, Geert left the liberal party to become an independent politician trying to form his own political group. In this new ideological phase, he had adhered to a neoconservative line marked by a criticism of the progressive hegemony in Dutch politics and in public debate, skepticism regarding the welfare state, permissive society, environmental policy and the consultation economy plus a growing concern with regard to the nature of Islam and the position of Muslims in Dutch society (VOSSEN, 2011, p.182).

In the second half of the 2000s, Geert Wilders managed to create the Partij voor de Vrijheid, clearly defined by its fight against immigration and supranational co-operation. It aimed at reassuring the country's identity, while also going against the political elite and in favor of the 'virtuous people' and their traditional families.

Whereas trajectories might differ, it is possible to identify the rise of similar politicians and political parties in different countries of Europe in the past years (ENYEDI, 2016; GRIMM, 2015; MAYER, 2013). The ascension of the Alternati- ve für Deutschland in the recent German federal election, altogether with the participation of the Freiheitliche Partie Österreichs and the Front $\mathrm{Na}$ cional in the presidential runoffs' second-round in, respectively, Austria and France, further evidence this trend.

Indeed, this topic was not totally relegated by Welzel (2013). A chapter later co-authored by him (WELZEL; ALVAREZ, 2014) based on his previous book discusses value orientations in comparison to views on democracy. One of the findin$\mathrm{gs}$ is that, even in strongly emancipative societies (majorly composed by Western European nations), people with low emancipative values tend to have a non-liberal notion of democracy, including what the authors label as the populist notion of democracy, composed by a major desire for economic growth and security. Whereas it demonstrates Welzel's acknowledgment of the co-existence of liberal and populist citizens in Western European countries, it does not explain the increase of populist parties in the region.

It is true that it was not Welzel's objective to address the issue of populism in neither of these two studies (WELZEL, 2013; WELZEL; ALVAREZ, 2014). Nonetheless, if emancipative values are on the rise (together with creative capital), why is such contradictory far-rise rise taking place among strongly emancipative societies?

\section{Emancipative values and creative capital versus cultural protectionism}

First of all, it is difficult to point out at any contradiction in the methodology used by Welzel (2013) to prove that emancipative values, or individualism, leads to socially benign orientations. When selecting questions from the World Values Survey to match with his concepts of collectivism 
and individualism, the former was identified as the mix of conformity and security desires against, for the latter, self-direction and stimulation.

Focusing on collectivism, two statements were mentioned to the interviewees who should state how much it sounded alike to their own thoughts. The statements were: "it is important to this person to always behave properly; to avoid doing anything people would say is wrong" (conformity), and "living in secure surrounding is important to this person, to avoid anything that might be dangerous" (security) (WELZEL, 2013, p.196).

The rejection of these elements represents an approximation to the emancipative values which, in this sense, is like Florida's (2002) creative class. Going specifically against the notion of conformity, Florida (2002, p.269) affirms that the creative class "wanted community, but not to the extent that they were inhibited from living their own life and being themselves. They did not want friends and neighbors peering over the fence into their lives".

This idea is the opposite of the one promoted by far-right figures as Geert Wilders. For them, traditional values should be conserved and the State should avoid the arrival of newcomers who would not adjust themselves to a so-called proper behavior. Furthermore, the far-right uses this speech to mix conformity with security, identifying migrants as potential criminals, as did Donald Trump; or terrorists, as does the Alternativ für Deutschland and its allied social movement, the Patriotische Europäer gegen die Islamisierung des Abendlandes (PEGIDA).

Another feature mapped by Welzel (2013) when perceiving the nature of individualism was the distinction between selfish and unselfish behavior. The first was marked by high scores for power and achievement against, for the second, universalism and benevolence. The relationship between these terms and the far-right speech is not as clear as the previous elements but it is still possible to draft a re- lationship. Universalism, for instance, was identified through the statement "looking after the environment is important to this person; to care for nature" (WELZEL, 2013, p.196). The main opponent of the Freiheitliche Partei Österreichs during the last presidential election in Austria was exactly the Die Grüne Alternative, the green, pro-nature, party.

Benevolence follows the same line. Once it is identified as "it is important to this person to help the people nearby; to care for their well-being" (WELZEL, 2013, p.196), it might be argued that far-right supporters are caring for the well-being of their own citizens but, at the same time, they are going against the inflow of migrants who were previously in inhumane conditions due to armed conflicts and poverty in their home countries. Thus, the benevolence of far-right movements is rather selective.

The opposite features, power and achievement, were measured through the statements, respectively, "it is important to this person to be rich; to have a lot of money and expensive things" and "being very successful is important to this person; to have an exciting life". Whereas it is not possible to argue that all far-right politicians use this kind of arguments in their speeches, Donald Trump's motto, 'Make America Great Again,' and his frequent self-praising discourses follow exactly these lines.

I argue therefore that the far-right and their voters could be placed on the opposite side of benign individualists at Welzel's "personal value space" graphic (WELZEL, 2013, p.198). Additionally, they could be identified as the opposite of Florida's (2002) creative class, due to their interest in preserving life as it was before.

As already mentioned, I acknowledge that it was not the objective of these authors to analyze the opposite group that they theorized. This kind of research was done, for instance, by Pippa Norris who went through the demand- and supply-sides of the radical right (NORRIS, 2005). As she found out, 
at individual level, attitudes toward cultural protection do help to explain why some people vote for these parties; the study demonstrates how negative feelings toward immigration, refugees, and multiculturalism predict whether somebody casts a ballot for a radical right party, even after including a range of prior controls for social background and political trust. Attitudes toward cultural protectionism prove far more significant predictors of radical right voting than economic attitudes. This pattern is found in nearly every country containing a relevant radical right party where we have data from the European Social Survey 2002, although there are two important exceptions to this pattern (Italy and Israel) (NORRIS, 2005, p.167).

Therefore, it makes sense to believe that the opposite groups to the ones analyzed by Florida (2002) and Welzel (2013) are the ones in the electoral basis of the far-right - or, at least the ones these populist leaders target at. Their cultural protectionism is marked by the collectivist attributes identified by Welzel (2013) as conformity and security. Or, acconding to Florida (2002), the strong ties that the creative class was trying to escape from.

But how do pro-cultural protectionism individuals react to the rise of emancipative values and the creative class? Bates (2014) tried to address a similar question. He argued that as emancipative values were on the rise, they could lead society to a culture of entitlements, where citizens would continuously demand more State intervention, resulting in a decline of economic freedom and growth. He verified that whenever economic problems were faced, citizens tended to change their preferences by demanding more growth, which was responded by policy-makers with more economic freedom. This phenomenon did not go against Welzel's (2013) theory but added a feature to it: freedom is rising but its pace might be slowed down in moments of economic crisis.
Norris (2005) did not find the same results when analyzing cultural protectionism. She could not identify any relationship between votes for far-right parties and ethnic diversity indicators, as "estimated official rates of refugees and asylum seekers, the proportion of nonnationals and noncitizens living in a country, or (...) public opinion toward immigration" (NORRIS, 2005, p. 187). On the other hand, as previously mentioned, at the individual level it was possible to predict that citizens with anti-immigrant and anti-refugee attitudes were more prone to vote for such parties. Therefore, it leads us to analyze the issue from the supply-side perspective.

Despite institutional reasons, Norris (2005, p.215-216) found out "that both ideological and populist appeals are part of the explanation for the attraction of radical right parties; indeed (...) ideological values and affective orientations toward parties reduced the significance of almost all of the social-demographic variables." It matches with the notion from Geert Wilders that he and his colleagues were just speaking out what the people already wanted to hear and say (VOSSEN, 2011). Additionally, it suggests that the number of people desiring cultural protectionism remained the same but they started having political representatives who they could vote for.

Another contributing factor to the far-right rise might also lie in the argument that the creative class, in some cases composed by migrants, has its political engagement restrained by some factors, as highlighted by Florida (2002).

For instance, many ethnically diverse communities are full of people working hard to gain a foothold in a new country, which leaves them little free time for civic affairs. Language or cultural barriers may further limit their ability to participate. They are also more likely to be excluded from or perceive that they are excluded from traditional avenues 
of political and civic participation. Perhaps many of them do not even hold U.S. citizenship or permanent resident status (FLORIDA, 2002, p.271).

Welzel (2013) showed evidence on the contrary direction. People with strong emancipative values tend to participate more in social movements - as similarly suggested by Bates (2014). Naturally, it does not necessarily include the migrants cited by Florida (2002) but at least it shows that nations which are welcome to diversity usually have strong socially liberal social movements.

Indeed, it is possible to theorize that this pro-diversity mobilization is among the causes of a trend of strengthening far-right parties. Once the public debate becomes centralized on emancipative discourses, it is the rational behavior of vote-seekers to offer a supply for electors prone to vote for anti-diversity candidates.

If this is right, we are capable of explaining the rise of far-right populism not as the increased number of citizens who are unhappy with the decline of their strong community ties but as the emergence of politicians and social movements capable of representing the cultural protection desires of unrepresented citizens. Furthermore, it leads us to infer that there is no mistake in suggesting the prominence of emancipation or creative capital. Still, Welzel (2013) and Florida (2002) did not anticipate the anti-diversity mobilization that would occur as a response to the increase in the share and political strength of socially liberal individuals.

\section{Methodological gaps and omissions}

Additional gaps and omissions might mislead decision-makers when transforming the findings of Florida (2002) and Welzel (2013) into public policies, especially when related to aspects that might ge- nerate clashes with the unorganized far-right. In this section I focus exclusively on methodological aspects, counting on insights from the existing literature.

First of all, I present the interesting debate between Florida (2002) and Glaeser (2004). The latter argued that, whereas there was merit in Florida's effort into merging creativity to the rise of bohemian lifestyles, his correlation between the creative class and city growth was not accurate. On the contrary, positive results were found because of the highly-educated profile of a great parcel of the creative class, implying that growth did not result from high diversity but from skilled professionals. According to Glaeser $(2004$, p.2), this difference would drastically change policy prescriptions: instead of "funky, socially free areas with cool downtowns and lots of density", these individuals desired "big suburban lots with easy commutes by automobile and safe streets and good schools and low taxes".

Florida's (2012) response was divided into two parts. First, he argues that whereas most of the creative class is composed of Bachelor-holder professionals, not all the Bachelor-holders are creative, therefore this special characterization is highly influential. Second, the measurement used by Glaeser (2004) differed from his. While Florida (2002) defined city growth as positive variations in output, Glaeser (2004) understood it as variations in the population.

Both arguments are relevant but do not settle the divide. They are indeed summarized by the measurement differences between both authors and it would be too normative to specify the ideal method for identifying city success. GDP growth is widely used by macroeconomic researchers in cros$s$-national studies but it also makes sense to do, as Edward Glaeser did in one of his books (GLAESER, 2012), to consider as successful the city which is capable of attracting more (especially highly-skilled) individuals. Malanga (2004), for instance, added measurements as employment and rate of 
formation of high-growth companies, as well as population growth, finding similar results as Glaeser (2004). Richard Florida's criticism could be exactly the same: different measures, different results.

Welzel (2013) had his work criticized by Alemán and Woods (2016) who divided their arguments into two parts. The first regards the use certain statistical measurements, for instance, national means as a coherent measurement for cross-country comparison and Cronbach's alpha as a manner of calculating a correlation coefficient between variables. As Alemán and Woods (2016) develop on the latter, this method is not proper when a high number of indicator variables is considered. Secondly, they find it contradictory to believe that people from non-Western regions will follow the same evolutionary trend towards liberal thinking given their different backgrounds, including cultural and timeframe divergences.

A response was given in the same journal's issue. Welzel and Inglehart $(2016,1069)$ understand that the ground for Alemán and Woods (2016) criticism was based on the following axiom: "when one uses individual-level data to create a multi-item index and then calculates group-level averages on this index, these averages are comparable only if they represent in each group the same pattern of inter-item convergence." The major argument contrary to this criticism is that

value configurations at the group level, most notably countries, describe prevalence features in collective mentalities. By definition, these prevalence features represent a culture-type phenomenon that only surfaces in the aggregate, hence, does not exist at the individual level. (...) For instance, the 'choice' and 'voice' components of emancipative values correlate at $\mathrm{R}=.22$ at the individual level. By contrast, aggregate measures of these components correlate at an $\mathrm{R}$ of .62 between countries. (...) An obvious conclusion from this observation is that weak and variable in- ter-item convergence within countries is (a) the norm and (b) irrelevant for convergence patterns that exist at the aggregate level between countries (WELZEL; INGLEHART, 2016, p.1071).

Furthermore, Welzel and Inglehart (2016) present the two quality criteria of combinatory constructs, which were used to analyze Welzel's emancipative values instead of a dimensional construct. In order to have predictiveness, combinatory constructs must have external validity, besides its internal consistency. In this sense, mentioning their previous research, Welzel and Inglehart (2016) argue that it was found

at exceptional strength and in meaningful ways with several dozen key indicators of (1) socioeconomic development, (2) cultural legacies, and (3) institutional performance (...). The correspondence of the value constructs with these aspects of social reality ranges from $60 \%$ to $80 \%$, across almost 100 countries representing more than $90 \%$ of the world population (WELZEL; INGLEHART, 2016, p.1075).

\section{Alternatives and negative implications}

Still, how these criticisms, be them valid or not, could evidence a gap in the constructs of Florida (2002) and Welzel (2013) especially in regards of their ability to foresee the rise of the far-right? I address the question based on the following diagram.

I assume that Welzel (2013) is right in arguing that economic development boosts emancipative values. Likewise, that the similarly liberal creative class generates economic development, as affirmed by Florida (2002). I include my own argument that increased socially liberal values incite the conservative part of the population to find its own representatives, or, following Norris (2005) 
FIGURE 1 - Economic development as the cause and consequence of socially liberal values

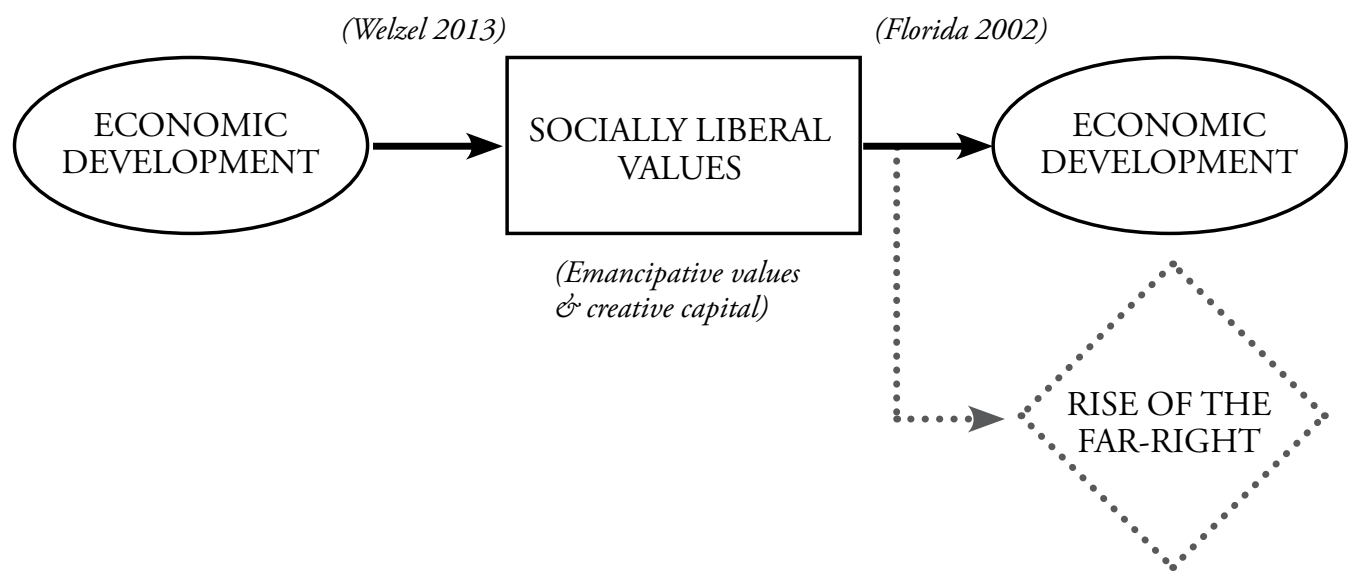

Source: designed by the author.

supply-side theory, that parties or political figures mobilize themselves under these circumstances as to offer themselves as an alternative to oppose the rising socially liberal policies and ideas.

Therefore, adopting the policy prescriptions Glaeser (2004) identified as a result of Florida's (2002) assumption would lead to an increased number of creative and bohemian citizens, maximizing their counterpart's incentives to become politically active by fighting against this trend. The same could be true for increases in emancipative values.

In the latter, whereas the aggregate mean of a country's emancipative values could be higher, its conservative part of the population would still exist and start being politically represented by far-right populist leaders, therefore capable of implementing undesirable reforms such as the recent Brexit. Whereas it does not invalidate Welzel's (2013) findings, it does evidence that the emergence of emancipative values may lead to a far-right mobilization capable of achieving real political gains for populist leaders.

In this sense, the Brexit example is insightful. The anti-migration campaign has been long supported by the United Kingdom Independence Party (UKIP) led by its former leader Nigel Farage. His party has received a small number of votes in the past general elections, accounting for $1.5 \%$ of the total turnout in $2001,2.2 \%$ in $2005,3.1 \%$ in
2010 and $12.7 \%$ in 2015 . Whereas the numbers have been growing throughout the years and achieved a four-fold increase between 2010 and 2015, they were enough for electing only one member of the parliament over its history. On the other hand, its leaders were among the key references for the Brexit vote, which won with $51.89 \%$ of the valid votes, accounting for $17,410,742$ backers in contrast to 390,563 UKIP voters in the general election of 2015. I do not claim that these 17 million citizens are supporters of UKIP but it is hard to imagine the existence and the results of this referendum without the existence and lobbying of this far-right populist party.

Finally, the case of Brexit highlights a key difference between the implications generated by Welzel's (2013) emancipative societies and Florida's (2002) creative class. Whereas the migration generated by both creative class's and emancipative value's ascension might be negatively perceived by the most conservative parts of society, they are essentially different issues. Emancipative values include tolerance for diversity and migration in all its senses, what means that people with any background are welcomed by these individuals. The creative class theory, on the other hand, is also highly tolerant towards migration but centers its efforts on attracting a specific kind of citizens, usually highly 
educated, equally liberal and creative. Therefore, the inflow of creative citizens indeed enhances the already existing liberal communities. Still, the emancipated individuals who favor free-movement also welcome conservative migrants who might end up opposing social liberalism.

I refer, for instance, to the mass migration from North Africa and the Middle East to Europe, which was composed of individuals from weakly emancipative societies going to strongly emancipative ones. They were desired by locals with high scores in emancipation but were potentially closer, despite different religious beliefs, to the more conservative parcel of their destination countries. Depending on how integration policies are to be developed, these incomers can either assimilate liberal values becoming part of the tolerant majority or keep their low emancipative values, adding up - in divergent groups - to the population that initially rejected them. One must research past episodes of mass migration, such as from Turkey to Germany in the mid- $20^{\text {th }}$ century, to design proper integration policies.

\section{Final remarks}

The present essay aimed at discussing the changes in social capital under the light of the theories of emancipative values and creative capital focusing on its potential impacts on the rise of the populist far-right. As mentioned earlier, my objective was not to create a new theory but to point out at some gaps and omissions in the assumptions and methods of Florida (2002) and Welzel (2013) that might have inhibited them to foresee the rise of a $21^{\text {st }}$-century mode of populism.

In the first section, I paved the ground for this paper by discussing relevant concepts as social capital, creative capital, emancipative values, and populism. I used the case of Geert Wilders to present what
I call far-right, or the $21^{\text {st }}$-century populism. It was followed by a further description of how the theories of emancipative values and creative capital contrapose cultural protectionism, positioning the far-right populists at the opposite side of Florida's (2002) and Welzel's (2013) ideal types in the political spectrum. Then, I presented the research of Norris (2005) who argued that the far-right's rise wasn't generated by an increase in the number of people supporting this ideology but by changes in the electoral supply, mainly through the re-organization or creation of political parties, improving the political representation of a pre-existing group of citizens. It means that Florida (2002) and Welzel (2013) were not wrong when identifying the increase of the creative class or emancipative values but, at the same time, they were not able to anticipate the far-right mobilization in response to this trend.

In the next section, I presented selected debate between these two authors and others who have presented gaps and omissions in their books, generally focusing on potential policy prescriptions. I referred not only to the critics but also to the responses given by Richard Florida and Christian Welzel. It helped me to construct a model where economic development leads to more social liberal societies, thus leading to both renewed economic development and the mobilization of the far-right. It becomes possible, as argued, given that a more social liberal society implies in changes in the lifestyle that certain conservative portions of a community might not be willing to accept. Moreover, as the mean values become more emancipative, it is possible that a greater gap between the average citizens and the least emancipated ones becomes big enough to motivate the latter's political engagement. Indeed, this political activation is far from generating a majority but it might be strong enough to influence decision making, as in the Brexit episode. 
As said, I do not find out any substantial mistake in the academic output of Richard Florida or Christian Welzel but limited theoretical developments certainly inhibited the ability to anticipate the current electoral trends. Thus, new studies and policy recommendations should be produced by academia as to better address the organization of populist far-right movements and avoid the growing divisionism and xenophobia found in recent elections in Western democracies.

\section{References}

ALEMÁN, J.; WOODS, D. Value Orientations from the World Values Survey: How Comparable Are They Cross-Nationally?, Comparative Political Studies v.49, p.1039-1067, 2016.

BATES, W. Where are emancipative values taking us?, Policy, v.30, p.12-21, 2014.

CONIFF, M. Populism in Latin America. Tuscaloosa: University of Alabama Press, 1999

ENYEDI, Z... Paternalist populism and illiberal elitism in Central Europe, Journal of Political Ideologies, v.21, p.9-25, 2016 FLORIDA, R. The Rise of the Creative Class. New York: Basic Books, 2002

FLORIDA, R. Cities and the Creative Class. City \& Community, v.2, n.1, p.3-19, 2003

FLORIDA, R. The Rise of the Creative Class Revisited. New York: Basic Books, 2012

GLAESER, E. Book Review of Richard Florida's "The Rise of the Creative Class”. Manuscript, 2004

GLAESER, E. Triumph of the City.Oxford: Pan Books, 2012

GRIMM, R... The rise of the German Eurosceptic Party Alternative für Deutschland, between ordoliberal critique and popular anxiety, International Political Science Review, v.36, p.264-278. 2015

INGLEHART, R. Modernization and Postmodernization: Cultural, Economic, and Political Change in 43 Societies. Princeton: Princeton University Press, 1997

INGLEHART R.; WELZEL, C. Modernization, Cultural Change, and Democracy: The Human Development Sequence. Cambridge: Cambridge University Press, 2005

KAUFMAN, R.; STALLINGS, B. The Political Economy of Latin American Populism. In: Dornbush, R.; Edwards, S. (eds.). The Macroeconomics of Populism in Latin America. Chicago: University of Chicago Press, 1991

MALANGA, S. The curse of the creative class, City Journal , v.4, p.36-45, 2004
MAYER N. From Jean-Marie to Marine Le Pen: Electoral Change on the Far Right. Parliamentary Affairs, v.66, p.160 178,2013

MUDDE, C.; KALTWASSER, C. Populism in Europe and the Americas: Threat or Corrective for Democracy?. Cambridge: Cambridge University Press, 2012

NORRIS, P. Radical Right: Voters and Parties in the Electoral Market. Cambridge: Cambridge University Press, 2005

PUTNAM, R. Making Democracy Work Again: Civic Traditions in Modern Italy. Princeton: Princeton University Press, 1994

PUTNAM, R.. Bowling Alone: America’s Declining Social Capital, Journal of Democracy v.6, p.65-78, 1995

VOSSEN, K. Classifying Wilders: The Ideological Development of Geert Wilders and His Party for Freedom, Politics v.31, p.179-189, 2011

WELZEL, C. Freedom Rising: Human Empowerment and the Quest for Emancipation. Cambridge: Cambridge University Press, 2013

WELZEL, C.; ALVAREZ, A. Enlightening People: The Spark of Emancipative Values. In: DALTON, R; WELZEL, C (eds.). The Civic Culture Transformed: From Allegiant to Assertive Citizens. Cambridge: Cambridge University Press, 2014

WELZEL, C.; INGLEHART, R. Misconceptions of Measurement Equivalence: Time for a Paradigm Shift, Comparative Political Studies, v.49, p.1068-1094, 2016 